\title{
Proximate and Bacteriological Analysis of Raw and Fermented Cheese in Ikole and Ado Ekiti, Ekiti State, Nigeria.
}

\author{
Edward $^{1}$, J.B., Oluwafemi ${ }^{1}, \mathrm{~K}$. \\ ${ }^{I}$ Department of Zoology, Faculty of Science, Ekiti State University, P.M.B. 5363, Ado-Ekiti, Ekiti State, Nigeria.
}

\begin{abstract}
This study was designed to investigate the proximate and bacteriological quality of raw and fermented cheese in Ikole and Ado Ekiti, Ekiti state, Nigeria. The results of the proximate analysis showed that the moisture content of raw cheese from Ikole was $88.20 \%$ and is higher than that from Ado-Ekiti. While the moisture content of fermented cheese from both study sites is the same, $71.09 \%$ and $71.09 \%$ respectively. The ash content of fermented cheese from Ado was $1.06 \%$ and is higher than the ash content of fermented cheese from Ikole which was $0.79 \%$, however, the ash content of raw cheese from Ikole (0.84\%) was higher than that of raw cheese from Ado (0.74\%). The fat content of fermented cheese from Ado and Ikole was observed to be significantly similar, having a value of $13.04 \%$ and $13.38 \%$ respectively, while the fat content of raw cheese from Ado was significantly higher (6.99\%) than that of raw cheese from Ikole (3.54\%). The mean crude protein of fermented cheese from Ikole is $9.18 \%$ which is higher than the mean crude protein of fermented cheese from Ado which is $8.70 \%$ and the crude protein of raw cheese from Ado and Ikole is significantly the same which is $3.88 \%$ and $3.68 \%$ respectively. The result of bacteriological analysis of raw and fermented cheese from Ikole and Ado Ekiti safe in terms of spores forming and Lactobacillus species, but not for mould spore, E. coli, Mesophilic bacteria, Bacillus, Coliforms, Staphilococcus aureus and shigella which may cause pathogenicity in raw and fermented cheese products.
\end{abstract}

Key Words: Raw Cheese, Fermented Cheese, Ikole, Ado, Quality.

\section{Introduction}

Cheese is the curd or hard substance formed by the coagulation of milk of certain mammals by rennet or similar enzymes in the presence of lactic acid from which part of the moisture has been removed by cutting, warning or pressing, which has been shaped in a mould and then ripened by holding for some time at suitable temperatures and humidity. "Wara" has been classified as a natural cheese made from milk and it is consumed in several parts of West Africa. The cheese is prepared by coagulating fresh cow milk with a leaf extract of Sodom apple (Calotropis procera). Wara processing involves the use of rudimentary equipment, in many cases, starter cultures are not used in processing and the conditions are not normally standardized or optimized. Although very recently, an alternative coagulant "lemon juice" was introduced into the processing of soft cheese to reduce microbial load (Adetunji et al., 2007).

The conventional method for the production of cheese has been discussed extensively. Cultures of Lactobacillus bulgaricus and Streptococcus thermophiles have been employed as starter cultures for cheese production (Frazier and Westhoff, 1988). For the production of high quality cheese, rennet enzymes is added for effective curdling and in its absence it is possible to use extracts from leaves of Sodom apple (Calotropis procera) as alternative. In the recent times, needs arise to develop an appropriate formulation for the production of cheese due to inconsistency in the uniformity of cheese being produced locally. In Nigeria, the Fulani pastoralists process surplus fresh milk into various stable products like West African soft cheese (Warankasi), Nono (fermented skimmed milk) and mai-shanu, the West Africa soft cheese which is the typical type of cheese found in Nigeria. It has a shelf-life of 2-3days when immersed in its whey. Cow milk (Wara) is an extremely nutritious drink with numerous vitamins and minerals. It is also an excellent source of proteins, fats and minerals (e.g. calcium, iron and phosphorus), vitamins and essential amino acids, thus making it an important food in the diet of both the old and young. The soft cheese produced in Nigerian farms especially in the northern part of the country makes use of local ingredients. The vegetable rennet used for the production is made from a native plant Calotropis procera (Sodom apple), which can be cultivated, all year round (FAO, 1994). The number of micro-organisms present at the time of milking has been reported to range between several hundreds and several thousand per milliliter (IDF, 1981). Due to the fact that wara is made up of milk, it contains various microflora and lactobacillus species which makes it susceptible to spoilage within a short period of time. Traditionally, it is preserved in its whey which last barely a day or two, it can be boiled in water to make it tough so as to increase its keeping quality which can last 3-4 days in a chilled condition (Belewu et al, 2005).

Cheese is usually stored in its whey and consumed fresh, but this can only last for 3-5 days after which spoilage occurs. It is sometimes fried and used as a meat-substitute in stews and soups, or smoke-dried to enhance its keeping qualities. However, all these increases it shelf-life by only a few extra days or few weeks at 
best (Belewu et al., 2005). The capacity to preserve cheese like any other food is directly related to the level of technological development. The slow progress in upgrading traditional food processing and preservation techniques in West Africa contributes to food and nutrition insecurity. Food processing techniques are thus essential not only to eradicate starvation and protein-energy malnutrition in the sub-region, but also to alleviate poverty by minimizing food wastage and generating income (Aworh, 2008). In the southern part of Nigeria, the Ekiti side to be precise, wara is a very scarce food type because of limited number of cattle rearers. Though, there are some fulanis with their cattles grazing around the green forest grasses, there are very few of their women seen around, selling cheese (wara). Considering the nutritious value of cheese, it is therefore imperative to investigate the quality of cheese produced by the Fulani cattle-rearers in two major towns (Ikole and Ado) in Ekiti State. This study is designed to investigate the bacteriological and proximate analysis of the raw fermented cheese collected from Ikole and Ado-Ekiti, and use this information to determine the nutritional value of raw and fermented cheese collected from these two towns.

\section{Materials And Method}

Fresh raw and fermented cheese was obtained from ten cows each in two different Fulani settlements in Ado and Ikole local government area, Ekiti state. The first Fulani settlement was in Ikole local government area of Ekiti State where the selected farm settlement was located beside Odo-Oro market in Odo-Oro Ekiti while the second one was located in Ayebode - Ekiti. The second Fulani settlement selected for this study was located in Ado local government area along Iworoko road before NNPC petroleum station Ado- Ekiti and the second one was located along Are-Afao road, Ado-Ekiti. Cheese samples were collected in clean sterile containers and immediately transported to the laboratory for analysis.

\section{Proximate Analysis of Cheese Samples}

The levels of moisture, protein, fat and ash in raw and fermented cheese samples were determined by the methods of Association of Official Analytical Chemists (AOAC, 2005). For moisture content, $5 \mathrm{~g}$ each of raw and fermented cheese samples were dried to a constant weight at $105^{\circ} \mathrm{C}$ for 3 hours with the aid of an electric oven (Astell Heason, England). Moisture content was taken as weight loss at the end of the drying period. Protein was determined by the micro-Kjeldahl method which estimated the amount of nitrogen in the sample and subsequently multiplied by a factor of 6.25 . Fat content was obtained by intermittent extraction with petroleum ether (B.P. $40^{\circ} \mathrm{C}-60^{\circ} \mathrm{C}$ ) using Soxhlet apparatus (Corning, England). Ash content was determined from the residue left after incineration of a weighed portion of the sample at $550^{\circ} \mathrm{C}$ using a muffle furnace.

\section{Microbial analysis of raw and fermented cheese}

From the cheese samples collected, $1 \mathrm{ml}$ of each variety was dispensed separately using sterile mortar and dissolved in $10 \mathrm{ml}$ of sterile distilled water. Serial dilutions from $10^{1}$ to $10^{-3}$ were made from the sample using pipettes. Dilutions of this sample were spread out on a plate using the modified pour plate technique.The plates were swirled for even distribution of innoculum and setting of agar. Thereafter, inoculated plates were incubated in an inverted position at $37^{\circ} \mathrm{C}$ for 48 hours. After incubation of bacteria, observation of plate for growth and colony count was done, and the means of randomly selected colonies in triplicates was recorded (Lateef et al., 2004). Selected isolates were sub-cultured and repeated streaking was done on steriled Mann Rogosa Sharpe (MRS) and NA plate accordingly to obtain pure cultures. The cellular and colonial characteristics of the isolates obtained were also studied. For the fungi, appropriate dilutions of cheese samples were made and surface-spread in triplicates and incubated at room temperature $\left(30-32^{\circ} \mathrm{C}\right)$ for $48-72$ hours. After incubation, the colonies were screened and identified based on the taxonomic schemes.

\section{Results}

Table 1 and 2 shows the result of proximate analysis of raw and fermented cheese in Ado-Ekiti and Ikole. It can be seen from this tables that moisture content recorded the highest percentage value amongst the parameters analyzed in both samples (i.e. Ado-Ekiti and Ikole). The moisture content of the raw samples were also higher than that of the fermented samples at both locations. Ash content had the lowest percentage value in both the raw and fermented cheese samples from the two locations. From Table 3, it can also be seen that there is no statistical difference $(\mathrm{P}<0.05)$ in mean moisture and fat content of both raw and fermented cheese from Ikole and Ado- Ekiti. However, the crude protein of raw cheese from Ikole (3.68 \pm 0.03$)$ is statistically lower than that from Ado samples $(3.88 \pm 0.03)$, while there is no significant difference $(\mathrm{P}<0.05)$ in the fermented cheese crude protein of samples from both locations (Ado and Ikole Ekiti) (see Table 3). 
Table 1: Proximate analysis of raw and fermented cheese Ado-Ekiti

\begin{tabular}{|l|l|l|l|l|}
\hline $\begin{array}{l}\text { Sample } \\
\text { locations }\end{array}$ & $\begin{array}{l}\text { Moisture } \\
\text { Content }(\%)\end{array}$ & $\begin{array}{l}\text { Ash } \\
\text { Content }(\%)\end{array}$ & $\begin{array}{l}\text { Fat } \\
\text { Content }(\%)\end{array}$ & $\begin{array}{l}\text { Crude } \\
\text { Protein }(\%)\end{array}$ \\
\hline F.C.A 01 & 69.11 & 0.95 & 14.70 & 9.02 \\
& 70.64 & 0.99 & 13.91 & 9.19 \\
\hline F.C.A 02 & 71.83 & 0.61 & 12.20 & 9.66 \\
& 72.81 & 0.63 & 12.71 & 8.85 \\
\hline R.C.A 01 & 84.93 & 0.82 & 7.00 & 3.88 \\
& 84.60 & 0.79 & 7.25 & 3.79 \\
\hline R.C.A 02 & 85.23 & 0.64 & 7.10 & 4.01 \\
& 84.33 & 0.60 & 6.63 & 3.84 \\
\hline
\end{tabular}

Note: F.C.A $=$ Fermented cheese Ado sample 01 and 02

R.C.A $=$ Raw cheese Ado sample 01 and 02

Table 2: Proximate analysis of raw and fermented cheese Ikole-Ekiti

\begin{tabular}{|l|l|l|l|l|}
\hline $\begin{array}{l}\text { Sample } \\
\text { locations }\end{array}$ & $\begin{array}{l}\text { Moisture } \\
\text { Content (\%) }\end{array}$ & $\begin{array}{l}\text { Ash } \\
\text { Content (\%) }\end{array}$ & $\begin{array}{l}\text { Fat } \\
\text { Content (\%) }\end{array}$ & $\begin{array}{l}\text { Crude } \\
\text { Protein (\%) }\end{array}$ \\
\hline F.C.I 01 & 70.44 & 1.15 & 13.72 & 8.64 \\
& 69.86 & 1.11 & 12.93 & 8.64 \\
\hline F.C.I 02 & 72.09 & 1.05 & 12.53 & 9.10 \\
& 71.95 & 0.94 & 12.98 & 8.43 \\
\hline R.C.I 01 & 89.02 & 0.66 & 3.98 & 3.68 \\
& 89.39 & 0.80 & 3.07 & 3.68 \\
\hline R.C.I 02 & 87.37 & 1.06 & 3.57 & 3.63 \\
& 87.02 & 0.84 & 3.53 & 3.71 \\
\hline
\end{tabular}

Note: F.C.I $=$ Fermented cheese Ikole 01 and 02

R.C.I $=$ Raw cheese Ikole 01 and 02

Table 3: Proximate composition of raw and fermented cheese from Ado and Ikole-Ekiti

\begin{tabular}{|l|l|l|l|l|}
\hline $\begin{array}{l}\text { Sample } \\
\text { Locations }\end{array}$ & $\begin{array}{l}\text { Moisture } \\
\text { content }\end{array}$ & $\begin{array}{l}\text { Ash } \\
\text { Content }\end{array}$ & $\begin{array}{l}\text { Fat } \\
\text { content }\end{array}$ & $\begin{array}{l}\text { Crude } \\
\text { protein }\end{array}$ \\
\hline Fermented cheese Ado & $71.09 \pm 1.11^{\mathrm{a}}$ & $1.06 \pm 0.09^{\mathrm{d}}$ & $13.04 \pm 0.49^{\mathrm{b}}$ & $8.70 \pm 0.28^{\mathrm{c}}$ \\
\hline Raw cheese Ado & $84.77 \pm 0.39^{\mathrm{a}}$ & $0.71 \pm 0.11^{\mathrm{d}}$ & $6.99 \pm 0.26^{\mathrm{b}}$ & $3.88 \pm 0.03^{\mathrm{c}}$ \\
\hline Raw cheese Ikole & $88.20 \pm 1.18^{\mathrm{a}}$ & $0.84 \pm 0.17^{\mathrm{c}}$ & $3.54 \pm 0.37^{\mathrm{b}}$ & $3.68 \pm 0.03^{\mathrm{d}}$ \\
\hline Fermented cheese Ikole & $71.09 \pm 1.59^{\mathrm{a}}$ & $0.79 \pm 0.20^{\mathrm{d}}$ & $13.38 \pm 1.13^{\mathrm{b}}$ & $9.18 \pm 0.35^{\mathrm{c}}$ \\
\hline P & $0.0001(0.05)$ & 0.0001 & 0.0001 & 0.0001 \\
\hline
\end{tabular}

Note:

$\mathrm{P}=$ Alpha level

Table 4: Microbial load of raw and fermented cheese from Ikole and Ado-Ekiti

\begin{tabular}{|l|l|l|l|l|l|l|l|}
\hline $\begin{array}{l}\text { Sample } \\
\text { Locations }\end{array}$ & $\begin{array}{l}\text { No } \\
\text { Mesophilic } \\
\text { Bacteria }\end{array}$ & No of Bacillus & No of E.coli & No of Coliform & $\begin{array}{l}\text { No of Shigella } \\
\text { sp. }\end{array}$ & $\begin{array}{l}\text { No } \\
\text { Staphilococcu } \\
\text { saureus }\end{array}$ & $\begin{array}{l}\text { No } \\
\text { Lactobacill } \\
\text { us sp. }\end{array}$ \\
\hline R.C.A & $3.56 \times 10^{5} \mathrm{cfu} / \mathrm{ml}$ & $2.60 \times 10^{5} \mathrm{cfu} / \mathrm{ml}$ & $\begin{array}{l}1.32 \times 10^{5} \\
\mathrm{cfu} / \mathrm{ml}\end{array}$ & $\begin{array}{l}2.21 \times 10^{5} \\
\mathrm{cfu} / \mathrm{ml}\end{array}$ & $\begin{array}{l}4.00 \times 10^{5} \\
\mathrm{cfu} / \mathrm{ml}\end{array}$ & $\begin{array}{l}4.9 \\
\mathrm{x} 10^{5} \mathrm{cfu} / \mathrm{ml}\end{array}$ & $\mathrm{np}$ \\
\hline F.C.A & $1.35 \times 10^{5} \mathrm{cfu} / \mathrm{ml}$ & $2.08 \times 10^{5} \mathrm{cfu} / \mathrm{ml}$ & $\begin{array}{l}1.07 \\
\mathrm{x} 10^{5} \mathrm{cfu} / \mathrm{ml}\end{array}$ & $1.9 \times 10^{5} \mathrm{cfu} / \mathrm{ml}$ & $3.08 \times 10^{5} \mathrm{cfu} / \mathrm{ml}$ & $\mathrm{np}$ & $\mathrm{np}$ \\
\hline R.C.I & $4.8 \times 10^{5} \mathrm{cfu} / \mathrm{ml}$ & $2.58 \times 10^{5} \mathrm{cfu} / \mathrm{ml}$ & $\begin{array}{l}1.22 \\
\mathrm{x} 10^{5} \mathrm{cfu} / \mathrm{ml}\end{array}$ & $4.05 \times 10^{5} \mathrm{cfu} / \mathrm{ml}$ & $6.06 \times 10^{5} \mathrm{cfu} / \mathrm{ml}$ & $\begin{array}{l}6.4 \\
\mathrm{x} 10^{5} \mathrm{cfu} / \mathrm{ml}\end{array}$ & $\mathrm{np}$ \\
\hline F.C.I & $4.8 \times 10^{5} \mathrm{cfu} / \mathrm{ml}$ & $6.9 \times 10^{5} \mathrm{cfu} / \mathrm{ml}$ & $\begin{array}{l}6.06 \\
\mathrm{x} 10^{5} \mathrm{cfu} / \mathrm{ml}\end{array}$ & $1.4 \times 10^{5} \mathrm{cfu} / \mathrm{ml}$ & $6.06 \times 10^{5} \mathrm{cfu} / \mathrm{ml}$ & $\mathrm{np}$ & $\mathrm{np}$ \\
\hline
\end{tabular}

KEYS: F.C.A: fermented cheese Ado-Ekiti

R.C.A: Raw cheese Ado

R.C.I: Raw cheese Ikole-Ekiti

F. C.I: Fermented cheese Ikole

NP: Not present

CFU: Colony forming unit

Ml: Mililitre 
Table 5: Growth of yeast and mould of both raw and fermented cheese in Ikole and Ado-Ekiti samples

\begin{tabular}{|l|l|l|l|}
\hline Sample locations & Total no of yeast spores & Total no of mould spores & Suspected organism \\
\hline Raw cheese Ado & $1.33 \times 10^{5} \mathrm{sfu} / \mathrm{ml}$ & $0.1 \times 10^{4} \mathrm{sfu} / \mathrm{ml}$ & Penicillium sp. \\
\hline Fermented cheese Ado & $6.5 \times 10^{5} \mathrm{sfu} / \mathrm{ml}$ & $\mathrm{np}$ & Penicillium motatum \\
\hline Raw cheese Ikole & $8.3 \times 10^{5} \mathrm{sfu} / \mathrm{ml}$ & $\mathrm{np}$ & Penicillium sp. \\
\hline Fermented cheese Ikole & $5.0 \times 10^{4} \mathrm{sfu} / \mathrm{ml}$ & $\mathrm{np}$ & $\mathrm{np}$ \\
\hline
\end{tabular}

Note: $\mathrm{SFU} / \mathrm{ML}=$ Spore forming unit/milliliter

\section{Discussion And Conclusion}

Wara "soft cheese" is unripened cheese, has an average shelf-life of 2-3 days when stored in whey at an ambient temperature of approximately $28^{\circ} \mathrm{C}$ (Adegoke et al., 1992; Belewu et al., 2005). It is an important protein substitute in the diet of the improverished rural dwellers for both young and old. The results obtained in this study indicated that raw cheese collected from Ikole-Ekiti had more moisture content than the one collected from Ado-Ekiti. This may be due to high water holding capacity of samples in this present study area and thus raw cheese from Ikole were able to retain higher level of moisture as suggested by Egan et al. (1987). Frazier and Westhoff (1988) had stressed that moisture content is a measure of the water content and accounts for the texture of cheese. Proximate analysis conducted in this study also showed that moisture content of fermented cheese from Ado is the same with fermented cheese from Ikole, that is, the water holding capacity of fermented cheese from both sampling locations were the same, and this may be due to the same processing it undergoes during fermentation.

The ash content of fermented cheese collected from Ado was observed to be higher than fermented cheese from Ikole, higher ash content signifies that a product is rich in minerals. This goes to say that fermented cheese from Ado seems to have higher concentration of mineral than that of fermented cheese from Ikole. For the raw cheese samples, the result of proximate analysis showed that ash content of raw cheese from Ikole was higher than that of raw cheese from Ado. The fat content of fermented cheese from Ado (13.04\%) is the same with fermented cheese from Ikole $(13.38 \%)$. This result is similar to the observation made by Wong et al. (1988) where they obtained a value of $12.7 \%$ for heat-acid coagulated cheese. However, the result of Fasakin and Unokiwedi (1992) (47.50\%) were at variance with result obtained in this study and previous ones by being much higher. This may be due to the fact that their product was not heat-treated as suggested by Uaboi-Egbenni et al. (2010). Significantly, fat is important as a source of energy to the body (Hennon et al., 2006) and are used by cells of organs and glands to provide energy and in the synthesis of some of their secretions (Kathleen et al., 1996).

The study of the protein content of fermented cheese from Ikole is $9.18 \%$ which is higher than those reported by earlier workers on fermented cheese (Frazier and Westhoff, 1988, 5.33\%) and lower than the value reported by Fasakin and Unokiwedi. (1992) (44.50\%). The protein content of this product shows that its consumption will help eliminate protein deficiencies that have become the bane of poor nations, Nigeria inclusive.

The result of microbial load of raw and fermented cheese from Ado and IkoleEkiti was displayed in Table 4. This results show that raw cheese from Ikole is $4.8 \times 10^{5} \mathrm{cfu} / \mathrm{ml}$. This shows that mesophilic bacteria have higher content in raw cheese from Ikole. Aakuet al. (2004) and Arenas et al (2004) reported on $5.5 \times 10^{6} \mathrm{cfu} / \mathrm{ml}$ and $10^{6}$ to $10^{7} \mathrm{cfu} / \mathrm{ml}$ of the total number of micro-organisms in pooled raw milk, respectively, which is higher than the present study $\left(4.8 \times 10^{5} \mathrm{cfu} / \mathrm{ml}\right)$. However, the mesophilic bacteria of fermented cheese from Ikole is $4.8 \times 10^{5} \mathrm{cfu} / \mathrm{ml}$ which is higher than fermented cheese from Ado $1.35 \mathrm{X} 10^{5} \mathrm{cfu} / \mathrm{ml}$, this may be due to unclean hands and materials used.

The total number of bacillus of fermented cheese from Ikole is $6.9 \times 10^{5} \mathrm{cfu} / \mathrm{ml}$ which is higher than fermented cheese from Ado. This result shows that presence of bacillus is higher in fermented cheese obtained from Ikole, this may be due to unhygienic conditions of the manufacturing unit. However, the growth of Bacillusspp. in raw cheese from Ado is $2.60 \times 10^{5} \mathrm{cfu} / \mathrm{ml}$, which is the same with raw cheese from Ado, this may be due to environmental variation.

The growth of E.coli in fermented cheese from Ikole is $6.06 \times 10^{5} \mathrm{cfu} / \mathrm{ml}$ which is higher than fermented cheese collected from Ado which is $1.9 \times 10^{5} \mathrm{cfu} / \mathrm{ml}$. However, although E. coli is a commonly occurring organism in milk and milk products as a possible cause of food-borne disease is insignificant, because $E$. coli normally is a ubiquitous organism (Hahn 1996). Also growth of $E$. coli of raw cheese from Ado and Ikole were the same $1.32 \times 0^{5} \mathrm{cfu} / \mathrm{ml}$ and $1.22 \times 10^{5} \mathrm{cfu} / \mathrm{ml}$ respectively. This result shows that ubiquitous organisms are present in raw cheese from Ikole and Ado Ekiti.

This result also revealed that total number of coliform in raw cheese from Ikole is $4.05 \times 10^{5} \mathrm{cfu} / \mathrm{ml}$ which is higher than raw cheese from Ado which is $2.21 \mathrm{X} 10^{5} \mathrm{cfu} / \mathrm{ml}$. This result shows that incidence of coliforms in raw milk has received considerable attention, partly due to their association with contamination of faecal origin and the consequent risk of more pathogenic faecal organisms being present, partly because of the spoilage, their growth in milk at ambient temperatures can produce and not least due to the availability of 
sensitive and rapid tests for detecting and enumerating coliforms. However, growth of coliform in fermented cheese from Ado and Ikole are $1.9 \times 10^{5} \mathrm{cfu} / \mathrm{ml}$ and $1.4 \times 10^{5} \mathrm{cfu} / \mathrm{ml}$ respectively. The growth of coliform in fermented cheese from Ado and Ikole are the same, this may be due to constant in temperature, because coliform are capable to grow at low temperature.

The total growth number of Shigella in fermented cheese from Ikole is $6.06 \times 10^{5} \mathrm{cfu} / \mathrm{ml}$ which is higher than fermented cheese from Ado which is $3.08 \times 10^{5} \mathrm{cfu} / \mathrm{ml}$. This result shows that fermented cheese from Ikole has higher growth of Shigella than fermented cheese from Ado. This may be due to unclean hands of workers, poor quality of milk and unhygienic conditions of the manufacturing unit and inferior quality of the materials used and water supplied for washing the utensils could be the source accelerating and the post manufacturing contamination of milk products and the post manufacturing contamination as well (Kumar and Sinha 1989; Masud et al., 1989; Kulshrestha, 1990). However, the growth of Shigella in raw cheese from Ikole is $6.06 \times 10^{5} \mathrm{cfu} / \mathrm{ml}$ which is higher that of raw cheese from Ado $\left(4.00 \times 10^{5} \mathrm{cfu} / \mathrm{ml}\right)$ this may be due to improper hygienic environment.

The total growth count of Staphilococcus aureus in raw cheese from Ikole is $6.4 \times 10^{5} \mathrm{cfu} / \mathrm{ml}$ which is higher than raw cheese collected from Ado which is $4.9 \times 10^{5} \mathrm{cfu} / \mathrm{ml}$. This result shows that there is presence of the most commonly occurring food poisoning incidences which is caused by the ingestion of the enterotoxin formed in food during the growth of certain strains of $S$. aureus. The toxin was termed as enterotoxin because it caused gastroenteritis or inflammation of the lining of the intestinal tract. However, this result revealed that raw cheese from Ado and Ikole-Ekiti is not good for direct consumption.

Moreover, fermented cheese from Ado and Ikole was not contaminated with S. aureus. This result shows that fermented cheese sold in Ikole and Ado was highly hygienic to Staphilococcus aureus. Also Lactobacillus sp. was totally absent in both raw and fermented cheese sold in various areas of Ikole and Ado can be considered as a hygienic food in terms of Lactobacillus spp.

The result of Table 5 revealed the growth of yeast and mould spores in raw and fermented cheese from Ikole and Ado Ekiti. The highest yeast spores count was obtained from the samples of raw cheese from Ikole area which is $8.3 \times 10^{5} \mathrm{sfu} / \mathrm{ml}$ and the lowest was from the raw cheese from Ado Ekiti which is $1.33 \times 10^{5} \mathrm{sfu} / \mathrm{ml}$. the acceptable standard count of spores forming bacteria was $<10,000 \mathrm{sfu} / \mathrm{ml}$ (Norrung 2000). The results of the present study showed that the raw cheese from Ado and Ikole-Ekiti contained spore forming bacteria below the standard acceptable level. Therefore, it could be said that raw and fermented cheese from Ado and Ikole can be considered as hygienic food in terms of yeast spores.

In mould spores, raw cheese from ado is $0.1 \mathrm{X} 10^{5} \mathrm{sfu} / \mathrm{ml}$, and the raw cheese from Ikole was totally absent. Generally, moldy or "mildewed" food is considered unfit to eat. Although molds are involved in the spoilage of many kinds of foods, some molds are useful in the manufacture of certain foods or as ingredients of food (Carroll, 2003). This result revealed that raw cheese from Ado are unfit to eat therefore, penicillum organism are suspected in raw and fermented cheese from Ikole and Ado Ekiti.

In conclusion, this result confirmed that raw and fermented cheese from Ikole and Ado-Ekiti is not suitable for direct consumption by population. Even more, it is also not appropriate for the manufacture of cow cheese without preceding milk heat treatment. Moreover, milk products, raw and fermented cheese sold in various areas of Ado and IkoleEkiti is safe in terms of spores forming and Lactobacillus species but not for mould spore, E. coli, Mesophilic bacteria, Bacillus, coliform, Staphilococcusaureus and Shigella which may cause pathogenicity in raw and fermented cheese products. As fermented cheese is produced through thermal evaporation of raw milk, contamination could occur during storage and use of unhygienic utensils.

Therefore, monitoring the hygienic conditions of the concerned area is of almost importance to prevent the bacterial contamination. Steps that should be taken to prevent bacterial contamination of foods include regular monitoring or inspection of the overall hygienic condition and following the recommendations of the institution and the international commission on bacteriological and proximate specification for foods, as well as an appropriate heat preparation for eradicating the food pathogens in the cheese samples.

\section{References}

[1] Aaku, E.N/Collinson, E.K/Gashe, B.A/Mpuchane, S. (2004) Microbiological quality of milk from two processing plants in Carotone Botswana.Food Control 15, 181-86.

[2] AOAC (2002): Association of official analysis chemists, Official Methods of Analysis, $17^{\text {th }}$ ed. Published by Association of Official of Analytical Chemists, Washing, D. C. 25, 17-25.

[3] Abou Zeid A.M, Hassan A.A, Ragheb R.R (1996). Mycological Studies on Skim milk soft cheese (Kareish) with quantitative evaluation of the existing mycotoxin. Proceedings of the $4^{\text {th }} \mathrm{Sci}$, Cong. Vet. Med. and Human Health. Vet. Med. J. Giza, 44 (2A): 113-121.

[4] Adegoke, G.O, Mse, and Akanni,E. M. A.O.,(1992). Effects of heat processing time and pH on the microflora, Alfa toxin content and storability of wara, a soft white cheese, D.C. Mahrung, 36:259-264.

[5] Adetunji, V.O, Alonge, R.K, Singh, \& Chen, J. (2007).Production of wara, a West African soft cheese using lemon juice as a coagulant. Journal Food Science and Technology 41(2), 331-336.

[6] Allcroft. R. Carnaghan R.B.A (1963), Groundnut toxicity: an examination for toxin in human food products from animals fed toxin groundnut meal, Veterinary Record 75: 259-263. 
[7] Alzbeta Medved'ova, Adriana StudeniCova, Lubomir Valik, and Ondrus Ladislav (2013) Microbial and sensory quality of raw milk cheeses from the milk vending machines. Acta Chimical Slovaca, Vol 6(1): 49-54.

[8] AmrAmer A. and Ekbal Ibrahim A. (2010) Determination of aflatoxin $\mathbf{M}_{1}$ in raw milk and traditional cheese, retailed in Egyptian markets. Journal of Toxicology and Environmental Health Sciences Vol. 2 (4), 50-53.

[9] Arenas, R./Gonzales, L./Bernardo, A./Fresno,/Tornadijo, (2004), M.E. Microbiological and physico-chemical changes in Genestoso cheese, a Spanish acid curd variety, throughout, ripening. Food Control 4(5), 271-279.

[10] Aworh OC, Egounlety M. (1985). Preservation of West African soft cheese by chemical treatment, J. Dairy Research 52; 189-95.

[11] Aworh, O.C. (2008). The role of traditional food processing technologies in national development: the west African experience in using food science and technology. To improve Nutrition and promote Nation development, Chapter 3 (Robertson, G.L.\&Lupien, J.R. Eds), International Union of Food Science and Technology (IUFOST).

[12] Aworh, S. and A. Akinniyi (1989). Proximate analysis and nutritional component of locally produced cheese. Nig. J. Food Sci. and Tech., 9: 220-227

[13] Blanco, J.L, Domingues L, Gomez. Lucia E, Garayzabaljff, Goyache J, Suarez G. (1988) Behaviour of aflatoxin during the manufacture, ripening and storage of manchego type cheese. J. Food Sci. 53; 1373-1376.

[14] Carroll, R. (2003). Making cheese, butter and yoghurt. Storey Publishing, M A. J. Food Sci. 72; 50-55.

[15] Chapman, H.R/Sharpe, M.E. (1990). Microbiology of cheese In: Dairy Microbiology (Ed: Robinson, R.K.), London, and New Jersey, Applied Science Publishers, 203-290

[16] Davis, J.G/Wilbey, R.A. (1990). Microbiology of cream and dairy desserts. In: Dairy Microbiology (ED: Robinson, R.K.) London and New Jersey, Applied Science Publishers, 41-108.

[17] De Buyser, M.L/Dufour, B./Maire, M./Lafarge, V. (2001). Implication of milk and milk products in food-borne disease in France and in different industrialised countries. J. Food Microbiol., 67, 1-2, 1-17

[18] Egan, H, R.S Kirk and R. Sawyer, (1987).Pearson's Chemical Analysis of Foods, 8th edition. Harlow, UK, Longman Scientific and Technical.

[19] EL-Sherief LM (2000). Incidence of mycoflora and some mycotoxins in locally manufactured cheese. M.V. Sc. Thesis, Fac. Vet. Med. Assiut Univ.pp 50-53.

[20] Fairbrain, D.J./Law, B.A. (1986). Protease of Psychrotrophic bacteria: their production properties, effects and control. J. of Dairy Res., 53, 139-177.

[21] Food And Agricultural Organization (FAO) (1994). Production yearbook 48; 281.

[22] Frank, J.K (1997). Milk and dairy products. In: food Microbiology, fundamentals and frontiers (Eds; Doyle, M.P/Beuchat, L.R/Montwille, T.J). Washington. DC: American Society For Microbiology 101-116, 581-594.

[23] Fasakin, A. and C. Unokiwedi, (1992). Chemical analysis of fermented cheese obtained from cow milk and melon. Nig. J.Microbiol, 5:559-566.

[24] Frazier, W.C and D.C Westhoff, (1988).Food Microbiology - Tata- McGraw-Hill publishers Co., New Delhi, pp:410

[25] Griffiths, M.W/Philips, J.D/Muir, D.D (1981) Thermostability of proteases and lipases from a number of species of psychrotrophic bacteria of dairy origin.J. ApplBacteriol 50, 289-303

[26] Hahn G. (1996).Pathogenic bacteria in raw milk situation and significance. In:Bacteriological quality of raw milk pp. 67-83. InterDairy Federation, Belgium.

[27] Jodral, M./Linam, E./Acosta, I./Gallego, C/ Rojas, F./ Bentabal(1993). A mycoflora and toxigenic Aspregillusflavus in Spanish milk: Inter. J. Food Microbiol, 18, 171.174

[28] Jodeph JK, AkinyosoyeFA(1997) Comparative studies on red sorghum extract and other chemicals as preservative for West African soft cheese. Inter Diary J. 193-198

[29] Jay J.M (1996).Modern Food Microbiology. ( $5^{\text {th }}$ ed) New York, Chapman \& Hall, 137.14, $328-342,347-352$.

[30] International Dairy Federation (IDF) (1981). New Monograph on UHT Milk Doc. 133, IDF, Brussels, Belgium.

[31] Kathleen J, Wilson W, Anne W (1996). Anatomy and Physiology in Health and Illness. $8^{\text {th }}$ Edition. Longman, Asia Limited, Hong Kong. 274.

[32] KarmenGoodic TORKAR and SLavicaGolc TEGER (2008) The microbiological quality of raw milk after introducing the two Day's milk collecting system. Acta Agricultural Slovenica 92 (1) 61-74

[33] Kulshrestha S.B (1990). Prevalence of enteropathogenic serogroups of E. coli in Milk products samples from Bareilly and their multiple drug resistance. Indian J. Diary Sci. 43. $337-378$.

[34] Kumar V and Sinha RN (1989).Incidence of coliforms in inidigenous milk products. Indian J. Diary Sc: 42, 579-580.

[35] Masud T. Athoir I.H, Chishti M.A, and Shah M.A (1989). Microbiological studies on indigenous Diahi with special reference to public health. J. Animal Health Prod. 8, - 13

[36] Nelson, F.E (1981) The microbiology of markel milk. In: Diary microbiology, (Editor: Robinson, Rick). The microbiology of milk. London and New Jersey, Applied Science Publisher, 165-207.

[37] NØrrung B (2000).Microbiological criteria for L. Monocytogenes in foods under special consideration of risk assessment approaches. Int. J. Food Microbiol. 62, 217-221

[38] Nwocc (2005).Effect of biological and chemical preservatives on the shelf life of West African soft cheese. Afr. J Biotechnol. 4; 1076-079

[39] Oladipo I.C and Jadesimi P.D (2013). Microbiological analysis and nutritional evaluation of West African soft cheese (Wara) produced with different preservatives. American Journal of Food and Nutrition. 3(1): 13- 21.

[40] Paul, L.H. M. (2004). Biochemistry of Cheese Ripening. Int. Dairy J. of Technology Vol (57) 2/3: 127-144.

[41] Rahman M.M, M. MashierRahman, S.M Arafat, AtiqurRahan, M.Z H.khan and M.S Rahman (2008).Microbiological quality assessment of a local milk product, kwacha Golla, of Bangladesh.J. Korean SOC. Appl Biol. Chem. 51 (4), 251-257

[42] Salmeron J./De Vegga, C./Perez - Elortondo, F.J/Albisu, M./Barron, L.J.R (2002) Effect of pasteurization and seasonal variations in the microflora of ewe's milk for cheese making. Food Microbiol,19 (2-3): 167-74.

[43] Stephen P. Oliver, Kathryn J. Boor, Steven C. Murphy and Shelton E. Murinda (2009). Food Safety Hazards associated with consumption of raw milk. Mary Ann Liebert, Inc. Pp: $793-806$.

[44] Uaboi - Egbeni P.O, Okolie P.N, AkintundeTil, Bisi-Johnson. O, Enwe L, and Bessong P.O (2010). Proximate Analysis and microbiological quality of cheese produced from raw cow milk obtained from Fulani settlement in Ogun State Nigeria, using lactic Acid Bacteria and extract from sodium Apple leaf (Calotropis procera), Pakistan Journal of Nutrition (9); 920-925.

[45] Wouters, J.T.M/Ajad, E.H.E/Hugenholtz, J/Smit, G. (2002). Microbes from raw milk for fermented dairy products. Int. Dariy J. 12, 91-109.

[46] Zerfiridis GK (1985). Potential aflatoxin hazards to human health from direct mold growth on Teleme cheese. J. Dairy. Sci, 68(9): 2184-2188. 